\title{
Algoritma Steganografi dengan Metode Spread Spectrum Berbasis PCMK
}

\author{
Septian Rheno Widianto \\ Prodi Teknologi Rekayasa Perangkat Lunak Politeknik En jinering Indorama \\ Kembang Kuning, Ubrug Jatiluhur, Purwakarta \\ septian.rheno@pei.ac.id
}

Diterima: 15 Oktober 2017. Disetujui 16 Oktober 2017. Dipublikasikan November 2017

\begin{abstract}
Abstrak - Kriptografi dan steganografi adalah dua alat untuk menawarkan keamanan data. Kriptografi menyediakan fitur seperti kerahasiaan, keaslian, dan integritas data. Steganografi biasanya terdiri dari dua sistem, yaitu sistem untuk menyembunyikan pesan dan sistem untuk mengambil pesan. Metode berbasis sistem chaos adalah metode yang berhubungan dengan suatu kegiatan atau kebiasaan sistem non-linear yang dinamis, dimana untuk beberapa kondisi menampilkan sebuah fenomena acak (chaos). Untuk membaca suatu pesan, penerima memerlukan algoritma yaitu crypto-key dan stego-key. Pada penelitian ini diajukan sebuah algoritma steganografi baru yaitu permutasi Chaotic berbasis multiputaran mengecil dan membesar (PCMPK/B) yang memiliki ruang kunci yang sangat besar, sehingga dapat diterapkan untuk metode steganografi dengan kebutuhan ruang kunci yang besar dan tahan terhadap brute force attack. Dari beberapa hasil analisis dapat disimpulkan kinerja algoritma steganografi yang dihasilkan tahan tehadap gangguan kompresi JPEG, terhadap noise standar (Gaussian noise, Poisson noise, Salt and Pepper noise, dan Speckle noise), terhadap kehilangan data, serta terhadap perubahan kecerahan dan kontras.
\end{abstract}

Kata Kunci: kriptografi, steganografi, chaos, pcmk/b, spread spectrum

\section{PENDAHULUAN}

Kemajuan teknologi internet, media digital seperti gambar, audio, video dan teks dibagi dan dikirimkan melalui Internet dengan lebih mudah. Namun, salah satu tantangan utama dalam berbagi dan mentransmisikan semua jenis informasi melalui saluran publik adalah keamanan data. Oleh karena itu, muncul kebutuhan untuk melindungi informasi yang akan dikirimkan dari penyadap dan pihak yang tidak berwenang[1].

Kriptografi dan steganografi adalah dua alat untuk menawarkan keamanan data. Kriptografi menyediakan fitur seperti kerahasiaan, keaslian, dan integritas data. Misalnya, kerahasiaan data dihasilkan melalui algoritma enkripsi yang mengacak/ menca mpur informasi pribadi sehingga menjadi tidak dapat dibaca oleh pihak selain penerima yang dimaksud. Secara khusus, dalam aplikasi kriptografi, pihak penyadap/pihak yang tidak berwenang mengetahui adanya informasi pribadi, dan tantangannya adalah menguraikan informasi yang dienkripsi. Di sisi lain, steganografi memberikan keamanan data dengan menyembunyikan informasi sehingga keberadaan pesan tersembunyi tidak diketahui oleh penyusup[2].

Citra digital digunakan sebagai pembawa informasi tersembunyi karena tingginya tingkat redundansi di dalamnya yang disebabkan oleh rendahnya sensitivitas sistem visual manusia, pesan tersembunyi mungkin dari jenis apa pun seperti teks, gambar, audio, atau video. Tantangan utama dalam aplikasi steganografi adalah bahwa pesan tersebut harus disembunyikan didalam gambar sedemikian rupa sehingga stego-image yang dihasilkan tidak menyimpang jauh dari citra aslinya, secara visual dan statistik[2].

Pada steganografi ada 3 hal penting yang perlu diperhatikan yaitu (1) imperceptibility, adalah keberadaan pesan tidak dapat dipersepsi oleh indrawi manusia, (2) fidelity, adalah mutu dari media steganografi tidak mengalami perubahan signifikan akibat proses penyisipan, dan (3) recovery, adalah pesan dapat diekstraksi sewaktu-waktu saat dibutuhkan [2].

Steganografi biasanya terdiri dari dua sistem, yaitu sistem untuk menyembunyikan pesan dan sistem untuk mengambil pesan. Dalam sistem-sistem tersebut terkandung enam komponen penyusun, antara lain [3]: (1) Pesan Rahasia, (2) Cover Document, (3) Stego Document, (4) Stego Key, (5) Fungsi Penyembunyi f' $(\mathrm{M}, \mathrm{C}, \mathrm{K}) \rightarrow \mathrm{Z}$, (6) Fungsi Detektor $\mathrm{f}^{\mathrm{f}}(\mathrm{Z}, \mathrm{C}, \mathrm{K}) \rightarrow \mathrm{M}$.

Steganografi dapat diterapkan pada hampir semua jenis file multimedia, tetapi yang paling sering digunakan adalah pada citra digital, karena pertukaran data dalam bentuk citra digital pada jaringan internet saat ini cukup tinggi, sehingga dapat mengurangi kecurigaan akan adanya pesan rahasia yang telah disisipkan. Cover dokumen dari komponen-komponen penyusun steganografi yang terdapat di steganografi gambar digital adalah sebuah citra digital atau biasa disebut cover-image. 
Steganogafi ini akan menghasilkan output berupa citra baru yang mengandung pesan yang sudah disembunyikan oleh algoritma steganografi yang disebut stego-image. Pengirim dan penerima harus memiliki kunci (stego-key) yang sama yang bersifat rahasia. Selain itu penerima harus menggunakan gambar yang mengandung pesan tersembunyi (stego-image) untuk dapat menerima pesan rahasia ters ebut[2].

Metode steganografi yang dipakai pada penelitian ini merupakan metode yang berbasis sistem chaos. Dalam ilmu fisika dan matematika, teori chaos berhubungan dengan suatu kegiatan atau kebiasaan sistem non-linear yang dinamis, yang untuk beberapa kondisi menampilkan sebuah fenomena acak (chaos). Chaotic merupakan suatu sistem yang dinamis yang mempunyai prilaku terbatas [2].

Dua karakteristik yang dimiliki sinyal Chaotic adalah spektrum daya yang kontinus pada suatu pita frekuensi tertentu, dari ciri ini menunjukan bahwa sinyal Chaotic merupakan sinyal yang non-linier sekaligus sering dikatakan sinyal noise, dan mempunyai kepekaan yang tinggi terhadap kondisi awal[4]. Pada aplikasinya sinyal Chaotic dapat berfungsi sebagai algoritma pemetaan dan sebagai pembangkit kode-kode random yang tidak mempunyai pola.

Spread spectrum dalam dunia komunikasi merupakan proses sinyal pita sempit dimodulasi oleh sinyal pita lebar yang akan menyebar sinyal pita sempit tersebut [5]. Dalam steganografi, sinyal pita sempit dianalogikan dengan hidden data yang akan disisipkan dan sinyal pita lebar dianalogikan sebagai citra digital yang telah didekomposisi wavelet atau media digital yang akan disisipi hidden data.

Pada penelitian ini, diajukan sebuah algoritma steganografi baru permutasi Chaotic berbasis multiputaran mengecil dan membesar (PCMPK/B) yang memiliki ruang kunci yang sangat besar, sehingga dapat diterapkan untuk metode steganografi yang tahan terhadap brute force attack serta dapat mengantisipas i kebutuhan ruang kunci yang besar.

Metode ini dikembangkan dalam perangkat lunak berbasis $\mathrm{C \# ,} \mathrm{dan} \mathrm{diimplementasikan} \mathrm{dalam}$ perangkat lunak Matlab untuk steganografi citra digital dengan tingkat keamanan tinggi, proses yang cepat, dan sekaligus tahan terhadap gangguan yang dapat digunakan untuk mengantisipasi perke mbangan pertukaran informasi melalui sosial media, M2M, dan IOT. Metode PCMPK/B juga diimplementasikan dalam algorit ma enkripsi Chaotic Encryption System (CES) yang dikembangkan dalam perangkat lunak berbasis $\mathrm{C}$.

\section{PEMBAHASAN}

Beberapa hal yang menjadi perhatian dalam pembahas an, yaitu :

\section{A. Steganografi}

Steganografi merupakan suatu ilmu atau seni dalam menyembunyikan informasi dengan me masukkan informasi tersebut ke dalam pesan lain. Dengan demikian keberadaan informasi tersebut tidak diketahui oleh orang lain[6]. Tujuan dari steganografi adalah menyembunyikan keberadaan pesan dan dapat dianggap sebagai pelengkap dari kriptografi yang bertujuan untuk menyembunyikan isi pesan. Oleh karena itu, berbeda dengan kriptografi, dalam steganografi pesan disembunyikan sedemikian rupa sehingga pihak lain tidak dapat mengetahui adanya pesan rahasia. Pesan rahasia tidak diubah menjadi karakter 'aneh' seperti halnya kriptografi[6].

Pesan tersebut hanya disembunyikan ke dalam suatu media berupa gambar, teks, musik, atau media digital lainnya dan terlihat seperti pesan biasa.

Dalam steganografi dikenal beberapa terminologi, yaitu : cover-data atau cover-text merupakan media penyembunyi pesan. Sedangkan hasil penggabungan antara cover-data dengan pesan yang disembunyikan disebut stego-text, stego-data, atau stego-object. Algoritma yang menghasilkan stego text disebut stegosystem. Pihak yang menciptakan stegosystem disebut steganografer[6].

Secara umum stego system terdiri dari tiga tahap yaitu algoritma untuk mendapatkan kunci, mengkodekan pesan, dan men-decode pesan. Algoritma tersebut dibungkus dalam suatu teknik tehnik penyembunyian pesan yang bermacam-macam [6].
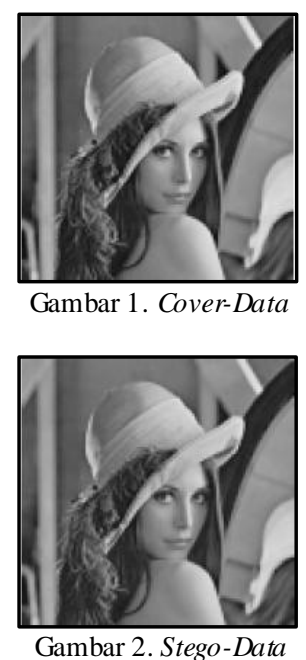

Gambar 1 merupakan file gambar lena.jpg yang dijadikan sebagai cover data. Sedangkan Gambar 2 merupakan file gambar lena.jpg yang telah dimasukan pesan rahasia berupa teks melalui aplikasi steganografi. Terlihat bahwa dengan mata manusia yang terbatas, perbedaan kedua gambar tersebut tidak terlihat. Keberadaan pesan rahasia di dalam Gambar 2 pun tidak dapat diketahui keberadaannya oleh pihak lain[7]. 


\section{B. Sistem Chaos (Chaos)}

Sistem chaos adalah sistem deterministik yang acak, namun definisi sistem chaos adalah tricky dan para ahli tidak menemukan kata yang sepakat untuk definisi chaos seperti disampaikan oleh Weisstein [8]. Hal ini juga sejalan dengan yang disampaikan oleh Gleick [9] bahwa tidak ada ahli sistem chaos yang diwawancarainya setuju dengan definisi dari kata chaos itu sendiri.

Perbedaan mengenai definisi chaos juga terdapat dalam beberapa buku yang menjadi referensi mengenai chaos, seperti Wiggins [10] berpendapat bahwa sebuah sistem dinamis yang menunjukkan sensitivitas terhadap nilai kondisi awal dalam set invariant yang tertutup dengan lebih dari satu orbit dapat disebut sebagai sistem chaos. Sementara itu Tabor [11] berpendapat bahwa solusi Chaotic adalah solusi deterministik yang memiliki hasil yang sensitif terhadap kondisi awal dan dalam phase space nampak sangat random.

Penjelasan tentang teori Chaos merujuk dari pendapat Kocarev dan Lian dalam bukunya ChaosBased Cryptography [12] seperti dijabarkan dalam bagian studi pustaka oleh Suryadi [1]. Teori Chaos merupakan sebuah teori yang pada awalnya berkembang dalambidang fisika.

Dalam pandangan teori chaos bahwa alam semesta yang tampak teratur atau terprediksi, ternyata tidaklah demikian. Hal tersebut diungkapkan oleh Edward Lorenz [13], yang pertama kali menemukan dan memperkenalkan fenomena chaos yang disebut dengan istilah "efek kupu-kupu". Chaos, menurut Ian Stewart [14] adalah perubahan yang sangat kompleks, iregular dan acak di dalam sebuah sistem yang deterministik. Chaos adalah suatu keadaan di mana sebuah sistem tidak dapat diprediksi akan ditemukan di tempat berikutnya. Sistem ini bergerak secara acak. Namun, bila keadaan acak tersebut diperhatikan dalam waktu yang cukup lama dengan mempertimbangkan dimensi waktu, maka akan ditemukan juga keteraturan. Karena bagaimanapun kacaunya sebuah sistem, maka sistem tidak akan pernah melewati batas-batas tertentu. Bagaimanapun acaknya sebuah sistem, ruang geraknya tetap dibatasi oleh sebuah kekuatan penarik yang disebut strange attractor. Strange attractor di satu sisi menjadikan sebuah sistem bergerak secara acak, dinamis, dan fluktuatif. Di sisi lain akan membingkai batas-batas ruang gerak tersebut[14].

\section{Spread Spectrum}

Metode spread spectrum dalam steganografi diilhami dari skema komunikasi spread spectrum, yang mentransmisikan sebuah sinyal pita sempit ke dalam sebuah kanal pita lebar dengan penyebaran frekuensi. Spread Spectrum Steganography terpencar-pencar sebagai pesan yang diacak (encrypt) melalui gambar. Untuk membaca suatu pesan, penerima memerlukan algoritma yaitu cryptokey dan stego-key. Metode ini juga masih mudah diserang yaitu penghancuran atau pengrusakan dari ko mpresi dan proses image (gambar) [15].

Pada proses penyembunyian data, bit-bit informasi yang telah mengalami proses spreading ini kemudian akan dimodulasi dengan pseudo-noise signal yang dibangkitkan secara acak berdasarkan kunci penyembunyian. Hasil dari proses modulasi ini kemudian digabungkan sebagai noise ke dalam sebuah berkas media pada bit-bit terakhir dari berkas media. Oleh penerima, sinyal dikumpulkan kembali menggunakan replica pseudo-noise signal tersinkronisasi. Media yang telah berisi informasi rahasia tersebut disaring terlebih dahulu dengan proses pre-filtering untuk mendapatkan noise. Noise yang dihasilkan selanjutnya dimodulasi dengan menggunakan pseudo-noise signal untuk mendapatkan bit-bit yang berkorelasi. Bit-bit yang berkorelasi tersebut dianalisa dengan perhitungan tertentu untuk menghasilkan bit-bit informasi yang sesungguhnya [15].

Berdasarkan definisi, dapat dikatakan bahwa steganografi menggunakan metode spread spectrum memperlakukan cover-object sebagai derau (noise) ataupun sebagai usaha untuk menambahkan derau semu (pseudo-noise) ke dalam cover-object. Coverobject sebagai derau sistem yang memperlakukan cover-object sebagai derau dapat menambahkan sebuah nilai ke dalam cover-object. Nilai ini harus ditransmisikan di bawah tingkat derau yang ditambahkan nilai ke dalamnya. Hal ini berarti kapasitas sangat ditentukan oleh cover-object.

\section{Analisis Stegano Citra}

Analisis stegano citra yang dilakukan untuk mengukur hasil kinerja metode stegano citra adalah: visualisasi, analisis statistik (histogram, korelasi, entropi, analisis kerandoman NIST), analis is diferensial (NPCR, UACI), analisis sensitivitas terhadap kunci (NPCR, UACI, korelasi), dan ruang kunci. Metode yang diusulkan juga diukur kinerjanya dari sisi ketahanan terhadap gangguan, diantaranya terhadap kompresi JPEG, terhadap gangguan standar (Gaussian noise, Poisson noise, Salt and Pepper noise, dan speckle noise), terhadap kehilangan data, serta terhadap perubahan kecerahan dan kontras.

\section{E. Algoritma Permutasi Chaotic Multiputaran Membesar (PCMB)}

Untuk mendapatkan set elemen asli dari elemen yang diacak menggunakan metode PCMPK adalah dengan melakukan permutasi multiputaran me mbesar (PCMPB) yang dikontrol oleh rangkaian kunci Key yang sama. Sebaliknya, pada PCMPK jumlah elemen yang terlibat dalam setiap ronde 
putaran pada PCMPB semakin berkembang yang secara visual [16] digambarkan dalam Gambar 3. Algorit ma PCMPB dijabarkan sebagai berikut:

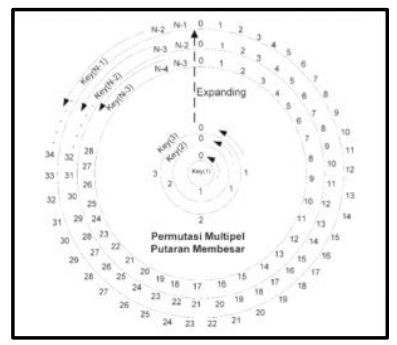

Gambar 3. Visualisasi Permutasi Chaotic Multiputaran Membesar (PCMPB) unt uk Elemen [16]

Algoritma PCMPK dan PCMPB digambarkan dalam Gambar 4 berikut:
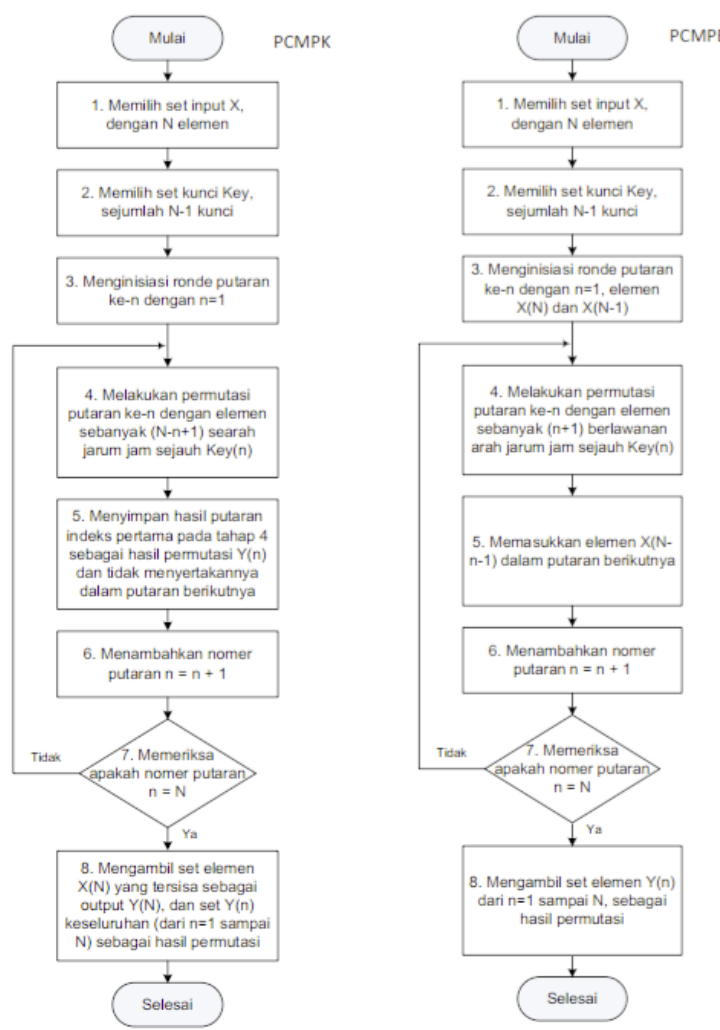

Gambar 4. Algoritma Permutasi Chaotic Multiputaran Mengecil (PCMPK) dan Membesar (PCMPB) [16]

1. Memilih set input $X$, dengan $N$ elemen.

2. Memilih set kunci Key sejumlah $N-1$ rangkaian kunci $\operatorname{Key}(n)$. $\operatorname{Key}(n)$ dapat dipilih sembarang angka bilangan bulat dalam ruang kunci sesuai dengan Gambar 3.

3. Menginisiasi ronde putaran ke- $n$ dengan $n=1$, dua elemen terakhir $X(n)$ dan $X(n-1)$.

4. Melakukan permutasi putaran ke-n dengan elemen sebanyak $(n+1)$ searah jarum jam sejauh $\operatorname{Key}(n)$.

5. Memasukkan elemen $X(N-n-1)$ pada elemen hasil putaran tahap 4 sebagai tambahan elemen input dalam putaran berikutnya.

6. Menambahkan nomer putaran $n=n+1$.

7. Memeriksa apakah nomer putaran $n=N$, jika tidak ulangi langkah 4 dan jika iya lanjutkan ke langkah 8 .

8. Mengambil set elemen $Y(n)$ dari $n=1$ sampai sebagai hasil permutasi PCMPB.

\section{F. Algoritma Permutasi Chaotic Multiputaran} Mengecil (PCMK)

Metode permutasi multiputaran memiliki dua pasang metode yaitu permutasi multiputaran mengecil (PCMPK) dan permutasi multiputaran membesar (PCMPB) yang merupakan proses kebalikan satu dengan lainnya. Visualisasi permutasi PCMPK [16]. berikut:

Algoritma PCMPK dijabarkan sebagai

1. Memilih set input $\mathrm{X}$, dengan elemen.

2. Memilih set kunci Key sejumlah $\mathrm{N}-1$ rangkaian kunci $K e y(n)$. Key(n) dapat dipilih sembarang angka bilangan bulat positif dalam ruang kunci sesuai dengan Gambar 5.

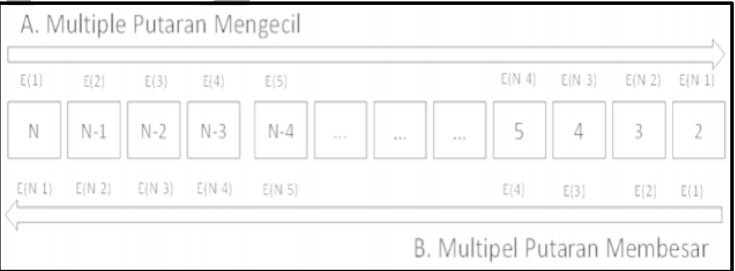

Gambar 5. Ruang Kunci untuk Tiap Tahap Putaran Permutasi Multiputaran. [16].

3. Menginisiasi ronde putaran ke-n dengan $\mathrm{n}=1$.

4. Melakukan permutasi putaran ke-n dengan elemen sebanyak $(\mathrm{N}-\mathrm{n}+1)$ searah jarum jam sejauh Key (n).

5. Menyimpan hasil putaran indeks pertama (Yn) pada tahap 4 sebagai hasil permutasi putaran pertama dan tidak menyertakannya dalam putaran berikutnya.

6. Menambahkan nomer putaran $\mathrm{n}=\mathrm{n}+1$.

7. Memeriksa apakah nomer putaran $n=N$, jika tidak, ulangi langkah 4, dan jika iya lanjutkan ke langkah 8 .

8. Mengambil set elemen $X$ (n) yang tersisa sebagai output $\mathrm{Y}(\mathrm{n})$ yang terakhir, dan set $\mathrm{Y}(\mathrm{n})$ dari $\mathrm{n}=1$ sampai $\mathrm{N}$ sebagai hasil permutasi PCMPK.

\section{METODOLOGI PENELITIAN}

\section{A. Perancangan Sistem}

Blok diagram steganografi pada citra digital adalah sebagai berikut : 


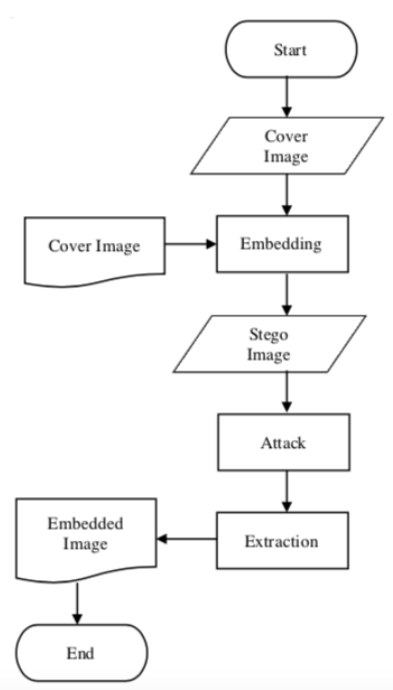

Gambar 6. Diagram Alir Sistem

\section{B. Penyisipan Pesan}

Diagram blok penyisipan pesan pada citra digital adalah sebagai berikut:

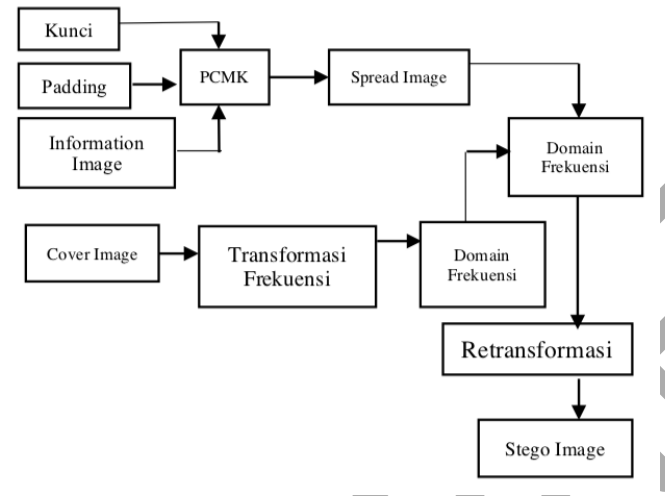

Gambar 7. Diagram Blok Penyisipan Pesan

\section{Ekstrasi Pesan}

Diagram Blok ekstrasi pesan pada citra digital adalah sebagai berikut:

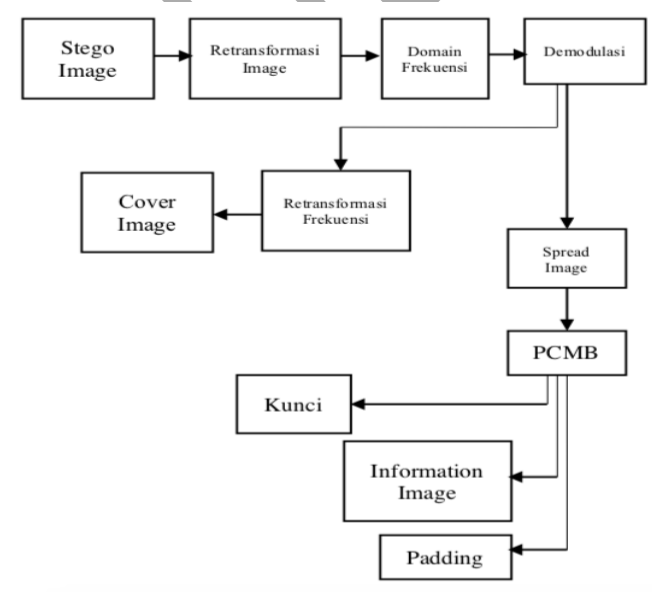

Gambar 8. Diagram Blok Ekstrasi Pesan

\section{PEMBAHASAN}

Penelitian ini bertujuan menghasilkan aplikasi steganografi berbasis Permutasi Chaotic Multiputaran Membesar dan Mengecil (PCMK/B) yang dibuat dengan menggunakan software Matlab_R2016b.

Algoritma steganografi berbasis PCMK/B yang dihasilkan merupakan algoritma steganografi yang tahan terhadap gangguan, gangguan yang dimaksud meliputi gangguan terhadap kompresi JPEG, terhadap noise standar (Gaussian noise, Poisson noise, Salt and Pepper noise, dan speckle noise), terhadap kehilangan data, serta terhadap perubahan kecerahan dan kontras.

\section{A. Pseudocode PCMK}

Percobaan permutasi chaotic multiputaran mengecil (PCMK) dilakukan pada software Matlab_R2016b, berikut ini adalah pseudocode dari PCMK.

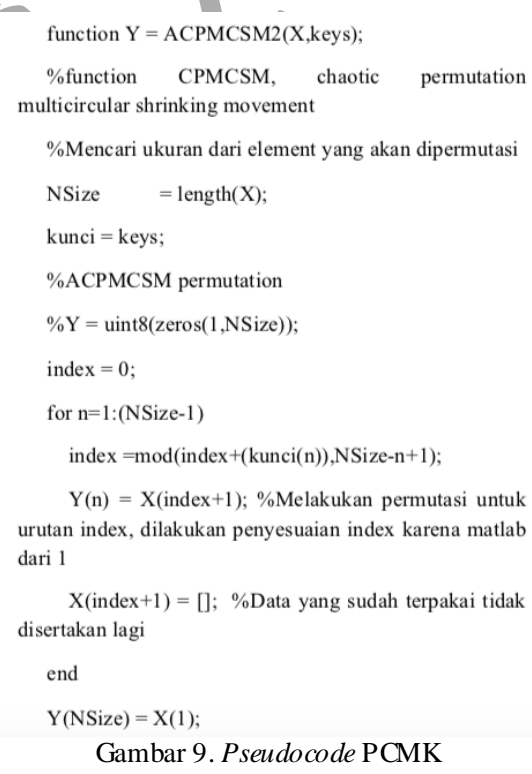

B. Pseudocode PCMB

Percobaan permutasi chaotic multiputaran membesar (PCMB) dilakukan pada software Matlab_R2016b, berikut ini adalah pseudocode dari PCMB. 


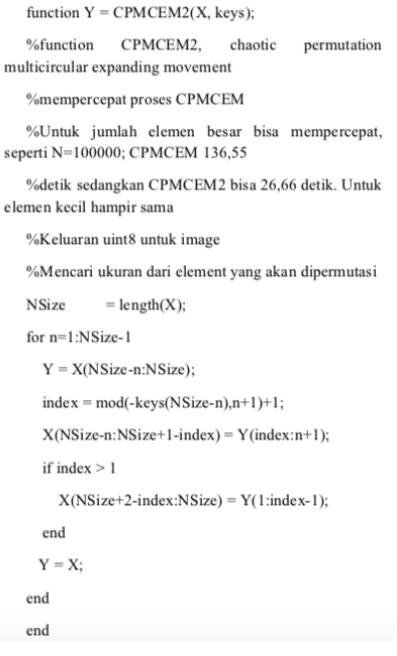

Gambar 10. Pseudocode PCMB

\section{KESIMPULAN}

Dari beberapa hasil analisis dapat disimpulkan kinerja algoritma steganografi yang dihasilkan dapat tahan tehadap gangguan gangguan terhadap kompresi JPEG, terhadap noise standar (Gaussian noise, Poisson noise, Salt and Pepper noise, dan speckle noise), terhadap kehilangan data, serta terhadap perubahan kecerahan dan kontras.

Algoritma steganografi digabungkan dengan metode spread spectrum berfungsi untuk menyebarkan informasi yang terdapat didalam embedded image sehingga tidak diketahui keberadaan/posisi dari pesan yang disisipkan tersimpan, sehingga pengirim pesan pun tidak mengetahui posisi dari pesan yang terdapat didalam embedded image.

Pada penyisipan pesan menggunakan Permutasi Chaotic Multiputaran Mengecil (PCMK) untuk proses yang bersumber dari kunci, padding, dan information image menghasilkan spread image yaitu mengacak in formasi yang telah didapatkan dari proses sebelumnya menjadi spread image. Proses dari cover image diawali dengan melakukan transformasi frekuensi menjadi domain frekuensi, kemudian disatukan dengan hasil dari proses spread image untuk dilakukan re-transformasi sehingga menghasilkan sebuah stego image.

Proses ekstrasi pesan diawali dengan stego image yang telah dihasilkan untuk dilakukan retransformasi image kemudian diubah kedalam domain frekuensi dan dilakukan demodulasi, dari proses demodulasi menghasilkan 2 proses yang pertama adalah melakukan re-transformasi frekuensi dan menghasilkan sebuah cover image dan yang kedua melakukan spread image menggunakan permutasi chaotic multiputaran membesar (PCMB) yang akan menghasilkan kunci, information image dan padding, meskipun pada hasil akhir padding yang ditambahkan pada proses awal tidak digunakan lagi pada hasil akhir dari proses steganografi citra.

\section{REFERENSI}

[1] M.Suryadi,"AlgoritmaBaruEnkripsiVideodenganMenggun akanMulti Chaotic Cipher Berbasis Galois Field (256) dan Transformasi Cosinus Diskrit Terkuantisasi," Disertasi Dokt or, Department of Electrical Engineering, Universitas Indonesia, Indonesia, 2013.

[2] Munir,R.(2004):“PengolahanCitraDigital",Informatika,Ban dung.

[3] Lin, Eugene T. and Delp, Edward J. "A Review of Data Hiding in Digital Image", http://www.ece.purdue.edu/ ace, 18 Juli 2004.

[4] Supangat, Suhono H., Juanda, Kuspriyanto "Watermarking sebagai T eknik P enyembunyian Label Hak Cipta pada Data Digital". ITB, Bandung. 2000.

[5] Marloe, Hamidah, "Implementasi Autentikasi Citra Digital Menggunakan Watermark Berupa Hash Citra Dengan Transformasi Fourier". STT Telkom, Bandung. 2003.

[6] Cachin (2005) : Digital Steganography

[7] R. Mutia S "Studi dan Pengujian Algoritma Steganografi pada Aplikasi Steghide", Institut Teknologi Bandung, Indonesia. 2017.

[8] W. Weisstein. (4/16/2015). "Chaos". Available: From MathWorld-A Wolfram Web Resource. http://math world. wolfram.com/Chaos.html.

[9] J. Gleick, Chaos: "Making a new science": Random House, 1997.

[10] S. Wiggins, "Introduction to applied nonlinear dynamical systems and chaos" vol. 2: Springer Science \& Business Media, 2003.

[11] M. Tabor, "Chaos and Integrability in Nonlinear Dynamics": An Introduction: Wiley-Interscience, 1989.

[12] L. Kocarev and S. Lian, "Chaos-based cryptography": theory, algorithms and applications vol. 354: Springer, 2011.

[13] N. Lorenz, "The essence of chao"s: University of Washington Press, 1995. Stewart, "Mathematics: The Lorenz attractor exists," Nature, vol. 406, pp. 948-949, 2000.

[14] P.Budi,“SteganografiPadaCitraDigit alMenggunakanMetod eSpread Spectrum Dan Metode Least Significant Bit (LSB) Modification", Universitas Islam Negeri Sultan Syarif Kasim Riau, Indonesia. 2011.

[15] Y. Suryanto, "Pengembangan dan analisis metode permutasi Chaotic baru berbasis multiputaran mengecil dan membesar untuk enkripsi citra dengan tingkat keamanan tinggi, cepat dan tahan terhadap gangguan”. Disertasi Program Doktor, Universit as Indonesia. 2016. 